\title{
Helping Reforestation in Southeast Asia The ASEAN-Canada Forest Tree Seed Centre Project
}

by

\author{
A.B. Case ${ }^{1}$ and B.S.P. Wang ${ }^{1}$
}

\section{Abstract}

The ASEAN-Canada Forest Tree Seed Centre Project is a key development initiative by Canada in addressing the growing deforestation problems in tropical regions. The Centre was established in 1981 as a cooperative venture between Canada and the Association of Southeast Asian Nations to help overcome difficulties in acquiring and producing operational quantities of high quality seed and planting material for regional reforestation programs. The Project entered its second phase in 1989 under the direction of Forestry Canada, Petawawa National Forestry Institute. Phase II of the Project is described in terms of Canada's inputs and the anticipated outputs over the 6-year period, 1989-1995.

\section{Résumé}

Initié par le Canada, le développement du Centre de semences forestières Canada-ASEAN est un programme-clé qui vise les solutions aux problèmes plus en plus graves du déboisement. Le Centre a été fondé en 1981, grâce à la coopération entre le Canada et l'Association des Nations de I'Asie du Sud-Est. Le but est de promouvoir la production et la collecte de semences forestières de grande qualité et en quantité suffisante pour les programmes régionaux de reboisement. Ce programme, dont la deuxième phase a commencé en 1989, est dirigé par l'Institut forestier national de Petawawa qui relève de Forêts Canada. Dans le présent document sont décrits les efforts déployés par le Canada de même que les résultats prévus au cours de la période de 1989-1995.

\section{Introduction}

Forests play a key role in the social, economic, and environmental stability of Southeast Asia. The alarming rate of tropical deforestation in the region is part of a serious global problem and is of paramount concern to the nations that are directly affected. The Association of Southeast Asian Nations (ASEAN)* has taken steps to address the problem through intensified reforestation programs with emphasis on increased planting - seen by many as the only solution to the problem for most ASEAN countries.

The forest plantation programs of ASEAN have been constrained by difficulties in acquiring and producing operational quantities of seed and vegetative planting material of known origin and high genetic quality. To help overcome this problem Canada has worked with the government of Thailand and the Association of Southeast Asian Nations since 1981 to establish and develop a Regional Forest Tree Seed Centre at Muak Lek, Saraburi Province, Thailand (Fig. 1). The Project was the first major cooperative venture between ASEAN and the Government of Canada and represents an important contribution to the reforestation efforts of the region.

TPetawawa National Forestry Institute, Chalk River, Ontario, Canada KoJ 1J0 *The ASEAN countries are Brunei Darussalam, Indonesia, Malaysia, the Philippines, Singapore and Thailand.

\section{Historical Perspecitve}

The concept of an ASEAN-Canada Forest Tree Seed Centre emerged in 1978 at the ASEAN-Canada Dialogue. In 1981 a Memorandum of Understanding was signed between the Government of Canada and the Royal Kingdom of Thailand (on behalf of ASEAN) thus marking the official start of the Project. The Centre (Fig. 2) was officially opened in January 1983 by the then Prime Minister, the Right Honorable Pierre Trudeau. Phase I of the Project, with extensions, continued until 1986 with Canadian contributions in the form of equipment, scholarships, technical training, and information exchange amounting to $C \$ 2.4$ million.

In 1984, the ASEAN countries requested continued Canadian support to the in-house research and development functions of the Centre, and to assist in applying the Centre's facilities and the skills of its personnel to support related development being conducted by other ASEAN agencies. An appraisal of the request confirmed that further development of the Centre would address the issue of genetic diversity and would help solve the forest tree seed supply problems of ASEAN. Accordingly, Canada agreed to support a second phase of development and, in 1988, a new Memorandum of Understanding was signed between ASEAN and Canada. Delivery of Phase II began in April 1989 when an administrative arrangement was signed between Forestry Canada and the Canadian International Development Agency designating 


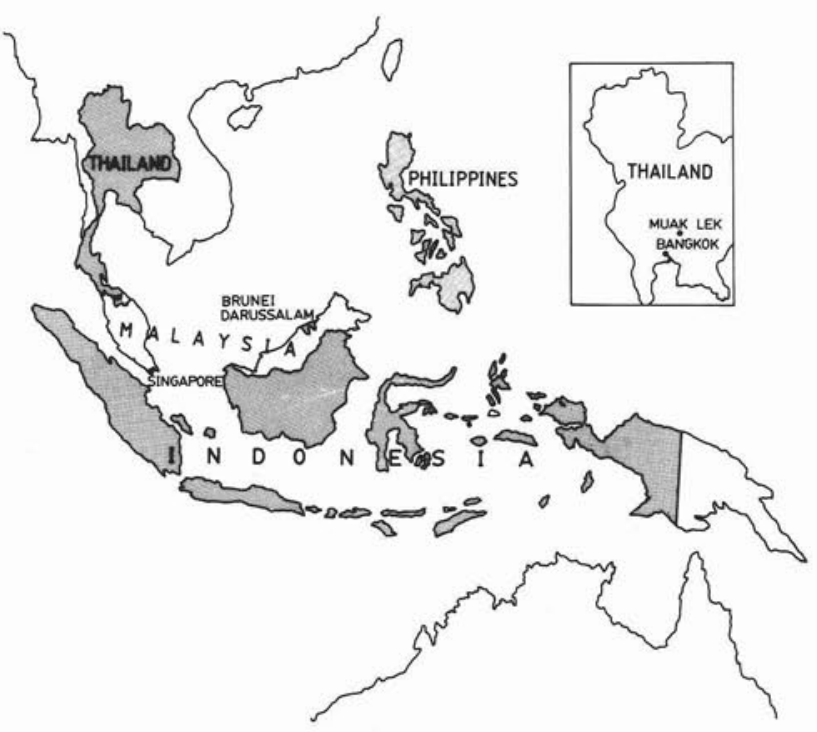

Figure 1. Map of ASEAN countries. Muak Lek is $150 \mathrm{~km}$ northeast of Bangkok.

the Petawawa National Forestry Institute (PNFI) as the Executing Agency for the Project. In this capacity PNFI is responsible for the coordination, administration, and management of all Canadian resource inputs to the Project. What follows is a description of Phase II of the Project, with emphasis on Canada's role through PNFI's participation as the Canadian Executing Agency.

\section{The Project}

\section{Scope}

The emphasis in Phase I was on seed research and management with a view to increasing the supply of high quality seeds of selected species for reforestation programs in the ASEAN. While the focus has not changed in Phase II, the scope has been broadened to stress the critical element of genetic management. Renewed emphasis is placed on training and professional development, information development and exchange, operational support to ASEAN participants, technology transfer, and intensified collaboration within and among the partner countries and agencies of the ASEAN.

The Project is valued at $C \$ 14.5$ million over the 6-year period, 1989-95. Canada will contribute C\$9.35 million while Thailand and other ASEAN countries will provide support in kind amounting to $C \$ 2.28$ million and $C \$ 2.87$ million, respectively. Canada's contribution will help provide the Centre with project management to assist in procurement of equipment and supplies, to arrange and support training in Canada and elsewhere, and to provide technical, administrative, and backup support for Canadians working in Thailand. Figure 3 shows the conceptual framework of the Project and illustrates Canada's role in project delivery.

\section{Project Organization}

There are five organizational elements in the implementation and management of the Project:

- The Canadian International Development Agency represents Canada and is responsible for funding and overseeing the Project.

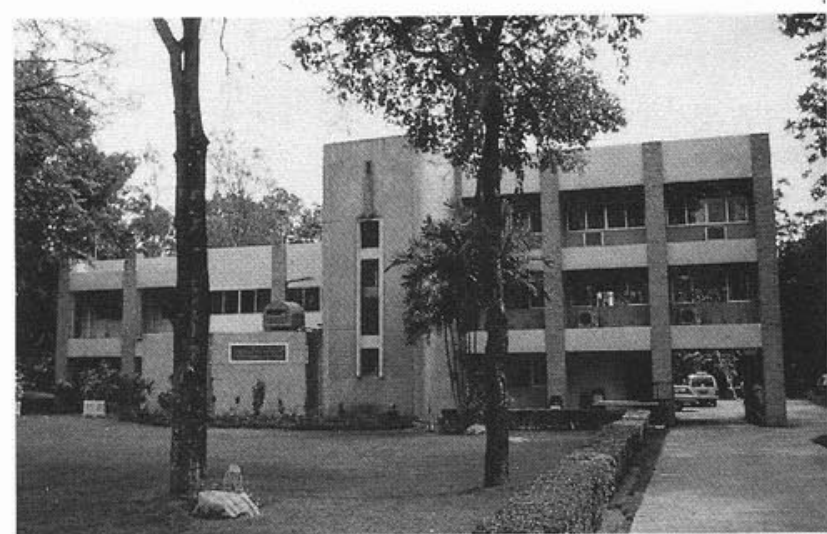

Figure 2. Headquarters building, ASEAN-Canada Forest Tree Seed Centre.

- The Petawawa National Forestry Institute (PNFI) of Forestry Canada serves as the Canadian Executing Agency, with responsibility for managing and administering Canada's inputs to the Project and for Project coordination.

- Thailand, represented by the Royal Forest Department of Thailand and the ASEAN-Canada Forest Tree Seed Centre, has overall responsibility for Project implementation.

- The Association of Southeast Asian Nations has responsibility for negotiating the MOU and for Project evaluation.

- ASEAN member country agencies have responsibility for execution of Project activities in collaboration with the Centre and PNFI.

\section{Project Direction}

A Steering Committee provides direction to the Project. The chairman is the Director General of the Royal Forest Department of Thailand; members include representatives from the ASEAN Secretariat, the Government of Canada, and from each of the ASEAN member countries.

The Committee meets at least once annually to set policy to ensure commitment to and coordinated implementation of all Project activities. There is review and approval of operating plans and progress reports to ensure that planned activities both address the development priorities of ASEAN member countries and are in line with Project goals.

\section{Objectives}

Phase II of the Project has two objectives. One is to increase the Forest Tree Seed Centre's capabilities to support and enhance the production, distribution, and utilization of high quality seed and vegetative planting materials in ASEAN. The other is to assist in identifying and conserving unique and valuable genetic resources in the region.

\section{Project Elements}

The Project is structured around four interrelated program elements: research and development, operational support, information exchange, and training.

\section{Research and Development}

This component of the Project focuses on the creation and introduction of technologies and methods that will help overcome technical constraints to successful large-scale seed and vegetative propagation operations. Included is a 

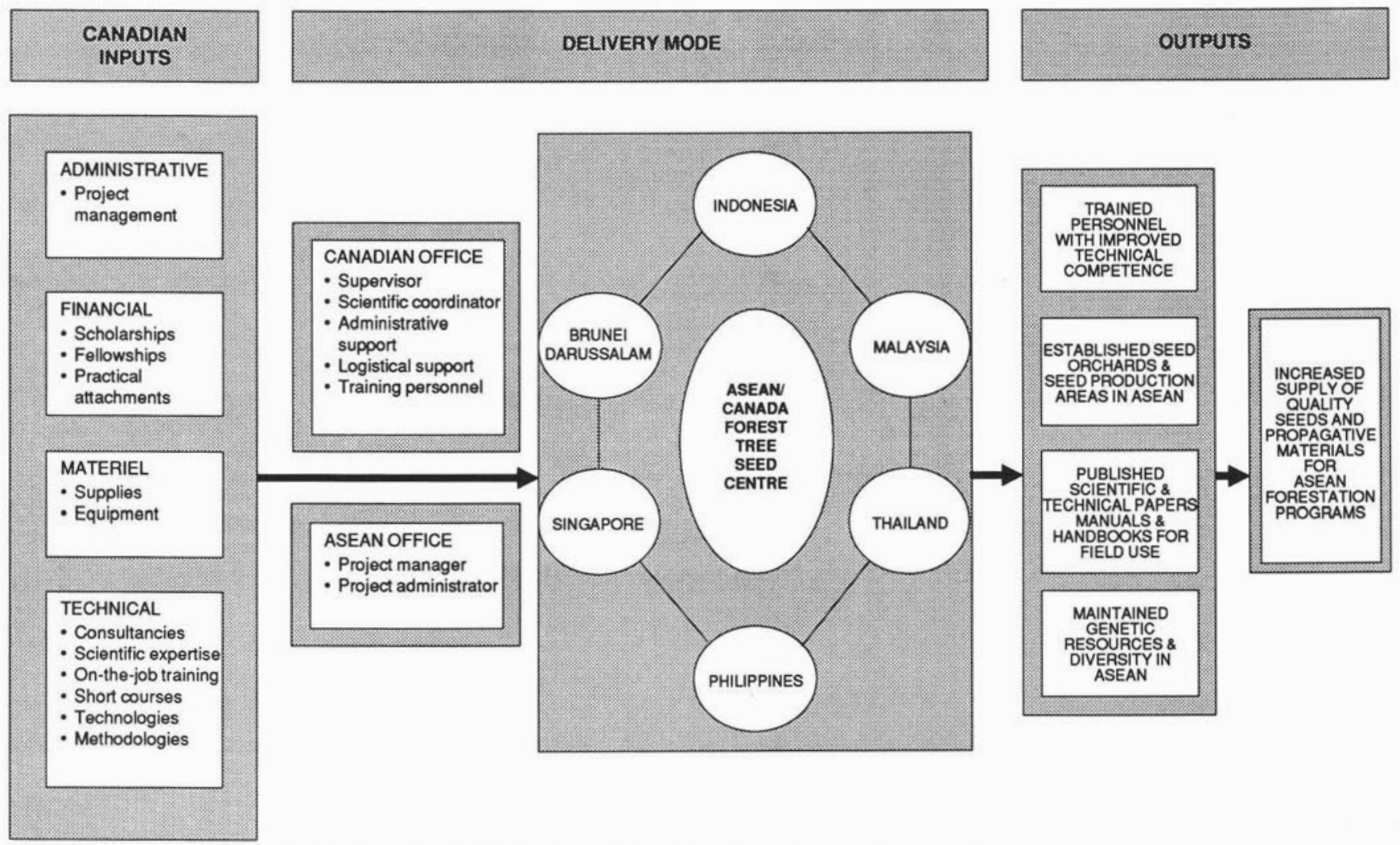

Figure 3. Conceptual framework of the ASEAN-CANADA Forest Tree Seed Centre Project illustrating Canada's role in implementation and delivery.

program of original research to support development work oriented to solve problems of established regional priority and which appear to be tractable in the short term and amenable to low technology solutions. The R \& D schedule applies to and crosses the four principal program areas of the Seed Centre: seed ontogeny and seed production, seed technology and materials exchange, seed origin and genetic resources, and stock production and nursery technology.

The Petawawa National Forestry Institute is pursuing the $R$ \& $D$ element of its mandate by:

- providing technical advisors to assist Centre staff and fellows from ASEAN agencies to design, conduct/contract, administer, and monitor state-of-the-art reviews in the major program areas;

- giving technical assistance through specialists to identify constraints to development of large-scale operational methods and to plan and conduct relevant research to overcome them;

- assisting Centre staff, ASEAN fellows, and working groups to identify short-term operational problems to plan and develop approaches and methods to overcome problems, and training personnel in the transfer and application of the methods;

- providing technical assistance to ASEAN participating agencies in planning, producing, and piloting seed testing and certification standards and putting them into operational use, as well as recommending and assisting the acquisition and installation of necessary equipment; and

- providing assistance in establishing editorial and publishing services and procedures to encourage technology transfer in seed science throughout ASEAN.

\section{Operational Support}

A key role of the Seed Centre is to provide operational support to forestry agencies in the ASEAN countries by obtaining and supplying specific seed and other genetic materials needed for trials and for development of seed orchards. The Centre provides consulting services in the areas of seed production, seed technology, planting stock production, design and management of species and provenance trials, and in a range of activities required to conserve and develop the diverse genetic resources contained both in endangered forests and forest types and exotic species of value in reforestation.

Canada, through the staff of the Petawawa National Forestry Institute and outside Canadian consultants, supports these elements in a variety of ways. For example, it is assisting the development of a fully operational seed and genetic materials exchange. This involves developing the facilities to serve as a model and training ground for originating, testing, and piloting new methods, and equipping the facility and developing training modules. Other means of support are provision of advice and assistance in planning and establishing trials, facilitating transfer of relevant technologies from Canada, and assisting in introducing and presenting trial methods. Direction in planning, selecting, establishing, and managing orchards and production areas for seed and propagation material is also an area in which Canada assists ASEAN.

Scientists from PNFI will help identify endangered forests and forest types and plan measures/programs for in situ and ex situ conservation of these threatened resources. They will aid development and maintenance of a registry of genetic resources in each participating country of ASEAN and 
provide direction on technology transfer techniques in areas of seed technology, seed and stock production, and genetic management. Finally, they will direct development of a program by the Centre to encourage public participation in establishing local plantations and orchards.

\section{Information Exchange}

As in much of the developing world, research and development throughout ASEAN has been hampered by a lack of access to regional and international literature, and by the paucity of professional contact among foresters, seed scientists, geneticists, nursery managers, as well as with centres in the rest of the world. The Information Exchange program is designed to address some of these drawbacks and to facilitate the flow of information to and among ASEAN agencies by developing a comprehensive library, an editing and publishing service, and regional information banks and exchange networks.

Canada will provide expertise, equipment, and training to the Centre and to counterpart agencies in ASEAN for development, expansion, and use of the library. This activity will include installation of an electronic system to facilitate acquisition, storage, retrieval, dissemination, and exchange of technical and scientific works. Facilities and procedures will be established for exchange of information and data among participating agencies.

Development of an editing and publishing facility will be a priority. At the end of Phase II, PNFI hopes to have built up the capacity within Thailand to edit and publish scientific papers by Centre staff, ASEAN fellows, and others in English, which is the common language of professional contact within ASEAN. Translation of existing works into some of the indigenous languages in the ASEAN region, such as Bahasa Malaysia, is being studied as a means of helping people in the field. The technical information facility will mesh with the publishing function on this. An efficient publications distribution system will also be set up.

Working Groups will be provided with guidance by PNFI specialists, and regular and ongoing activity by these important groups will be ensured. Canada will support Centre staff and ASEAN fellows in attending international meetings.

\section{Training}

Training for self-sufficiency is the key element in Canada's commitment to the ASEAN-Canada Forest Tree
Seed Centre. This will be achieved through fellowships, scholarships, practical attachments, short-term training courses, and seminars/symposia. Canada will provide experts to plan, conduct, and monitor on-the-job training for Centre staff and ASEAN fellows with support in the form of financial grants and allowances.

Scholarships will be awarded for postgraduate training in Canada to qualified candidates from the Centre and collaborating ASEAN agencies, the goal being to develop their abilities as lead personnel in the areas of forest tree seed and genetic resources both during and after the Project. Canadian specialists will also identify opportunities for and arrange, organize, and fund a series of practical attachments and technical tours that cover modern methods employed in seed technology and genetic resources operations and development. Canadian expertise will be tapped to provide short training courses for Centre staff and ASEAN personnel.

There will be participation in selecting candidates for training, involvement in planning tours and course content, and arranging itineraries. All arrangements in Canada and elsewhere with cooperators will be coordinated by Project managers in Canada. A useful initiative that is being organized in cooperation with the Working Groups is a series of four symposia that will enable ASEAN personnel to obtain insights into developments in seed science and technology and genetic conservation elsewhere in the world. This will afford an opportunity to present and discuss seed science developments in ASEAN with experts from all over the world.

\section{Conclusion}

The ASEAN-Canada Forest Tree Seed Centre is an important initiative that will help ameliorate some of the problems caused by deforestation in this part of the tropics. The 6-year, C\$14.5 million Phase II of the Project will strengthen the Centre's capacity to provide technical assistance to ASEAN countries in their reforestation programs. The Centre will be technically equipped and have a trained staff to serve as a regional training centre on seed research and management for the ASEAN countries, and to assist in supplying operational quantities of seed for ASEAN reforestation programs. Through the training and development activities a core of trained personnel will be developed throughout ASEAN to ensure continued benefits to the region.

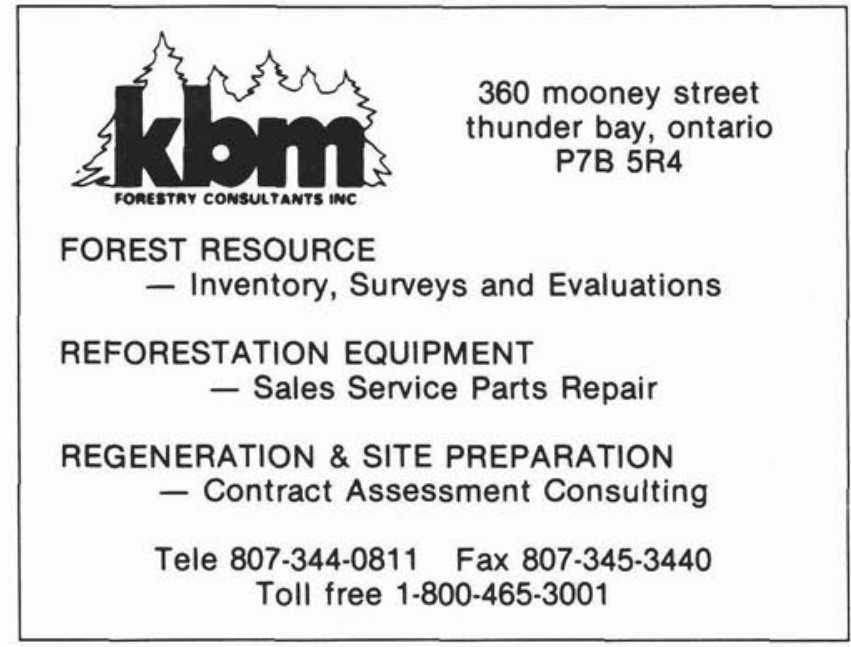

